\title{
Association Between Osteoarthritis and Urinary Tract Infection in Older Adults: A Nationwide Population-Based Cohort Study
}

\section{Wei-Hung Wang}

Chi Mei Medical Center

Tian-Hoe Tan

Chi Mei Medical Center

Chung-Han Ho

Chi Mei Medical Center

Yi-Chen Chen

Chi Mei Medical Center

Chien-Chin Hsu

Chi Mei Medical Center

Hung-Jung Lin

Chi Mei Medical Center

Jhi-Joung Wang

Chi Mei Medical Center

Chien-Cheng Huang

Chi Mei Medical Center

Yen-wei Chiu ( $\nabla$ u9922410@cmu.edu.tw)

Chi Mei Medical Center

\section{Research Article}

Keywords: urinary tract infection, hospitalization, older adult, osteoarthritis.

Posted Date: January 13th, 2021

DOI: https://doi.org/10.21203/rs.3.rs-141141/v1

License: (c) (i) This work is licensed under a Creative Commons Attribution 4.0 International License. Read Full License 


\section{Abstract}

Background: Osteoarthritis (OA) may increase urinary tract infection (UTI) in older adults. However, this issue remains unclear.

Methods: We identified 8599 older patients ( $\geq 65$ years) with OA, and an equal number of older patients without OA, matched by age, sex, and index date from the Taiwan National Health Insurance Research Database between 2001 and 2005. Past histories, including UTI and underlying comorbidities, were included in the analyses. Comparisons for any UTI, $\geq 1$ hospitalization for UTI, and $\geq 3$ hospitalizations for UTI between the two cohorts by following up until 2015 were performed.

Results: In both cohorts, the percentages of age subgroups were 65-74 years (65.7\%), 75-84 years $(30.1 \%)$, and $\geq 85$ years $(4.2 \%)$. The male sex was $42.4 \%$. Patients with OA had an increased risk of any UTI compared with those without OA after adjusting for all past histories (adjusted hazard ratio [AHR]: 1.72; $95 \%$ confidence interval [Cl]: 1.64-1.80). The Kaplan-Meier curve and log-rank test showed that OA increased any UTI $(p<.001)$. Compared with patients without OA, patients with OA also had an increased risk of $\geq 1$ hospitalization for UTI and $\geq 3$ hospitalizations for UTI (AHR: 1.13; 95\% Cl: 1.06-1.19 and AHR: $1.25 ; 95 \% \mathrm{Cl}: 1.13-1.38$, respectively). In addition to OA, older age, female sex, history of UTI, benign prostatic hyperplasia, indwelling urinary catheter, cerebrovascular disease, diabetes, dementia, and urolithiasis were independent predictors for any UTI.

Conclusions: OA increased UTI in older adults. We suggest appropriately managing OA and controlling underlying comorbidities to prevent subsequent UTI.

\section{Introduction}

The aging population is an important worldwide issue. In the United States, the older population ( $\geq$ 65 years) is projected to grow from 49 million to 95 million between 2020 and 2060[1]. In Taiwan, older adults were $14 \%$ of the total population in 2018 , and are projected to be $20 \%$ in 2025 [2]. The percentage of very old adults ( $\geq 85$ years) in the older population will increase from 10.3-27.4\% between 2020 and 2070 [2]. Urinary tract infections (UTIs) are responsible for $15.5 \%$ of hospitalizations and $6.2 \%$ of deaths attributable to infectious diseases in older adults[3]. In institutionalized adults, UTIs are the most common infections $[4,5]$. Recurrent UTIs in older adults increases morbidity, mortality, and personal and social burdens[6].

Osteoarthritis $(\mathrm{OA})$ is the most common joint disease and one of the most frequent causes of pain and disability[7]. OA was found in many older adults, and nearly $80 \%$ of older people aged over 75 years[7]. In the United States, OA is the second cause of work disability in men over 50 years of age[7]. OA of the knee and hip can affect walking, climbing stairs, and self-care, and eventually result in decreased quality of life $[8,9]$. Because of pain and decreased physical activity, OA is associated with higher healthcare usage and increased risks of obesity, depression, cardiovascular disease, renal disease, and diabetes[10]. A previous study reported that decreased physical activity might increase UTI[11]. However, we did not 
find any study about the association between OA and UTI in older adults by searching using the keywords "older adult," "osteoarthritis," and "urinary tract infection" in PubMed and Google Scholar. Therefore, we conducted the present study to investigate this issue. We hypothesized that UTI might increase in older adults with $O A$.

\section{Methods}

\subsection{Data source}

This nationwide population-based cohort study was conducted using the Longitudinal Health Insurance Database 2000 (LHID 2000), which is a data subset from Taiwan's National Health Insurance Research Database (NHIRD) [12]. The National Health Insurance system of Taiwan covers more than $99.6 \%$ of the Taiwanese population, and the claims data of this system are released as the NHIRD $[12,13]$. The LHID 2000 contains 2,000,000 individuals randomly sampled from the NHIRD using random number generators[12]. The distribution of age and sex are not different between patients in the LHID 2000 and those in the NHIRD[12].

\subsection{Study design, setting, and participants}

We identified older patients ( $\geq 65$ years) with OA between 2001 and 2005 as the study cohort and an equal number of older patients without $\mathrm{OA}$ by matching age, sex, and index date as the comparison cohort. The diagnosis of OA was defined when the patient had the diagnosis of International Classification of Diseases, Ninth Revision, Clinical Modification (ICD-9-CM) of 715 or 721, and at least one hospitalization or three outpatient clinic visits. Underlying comorbidities and potential risk factors for UTI $[14,15]$, including a history of UTI, benign prostatic hyperplasia (BPH), an indwelling urinary catheter, cerebrovascular disease, diabetes, dementia, and urolithiasis were included in the analyses.

\subsection{Definitions of variables}

The age subgroups were classified as $65-74$ years, $75-84$ years, and $\geq 85$ years[ $16-19]$. We defined the underlying comorbidities as follows: a history of UTI (ICD-9-CM 590, 595, 597, 599.0, 601), BPH (ICD-9-CM 600 ), indwelling urinary catheter (ICD-9-CM Vol. 3 Procedure Codes 57.94), cerebrovascular disease (ICD9-CM 430-438), diabetes (ICD-9-CM 250), dementia (ICD-9-CM 290, 294.1, 294.2, 331), and urolithiasis (ICD-9-CM 592, 594). We further divided OA into four subtypes: the upper limbs (ICD-9-CM 715.04, 715.11, $715.12,715.13,715.14,715.21,715.22,715.23,715.24,715.31,715.32,715.33,715.34,715.91,715.92$, 715.93, 715.94), lower limbs (ICD-9-CM 715.15, 715.16, 715.17, 715.25, 715.26, 715.27, 715.35, 715.36, 715.37, 715.95, 715.96, 715.97), spine (ICD-9-CM 721.0, 721.1, 721.2, 721.3, 721.41, 721.42, 721.5, 721.6, 721.7, 721.8, 721.90, 721.91), and others (ICD-9-CM 715.00, 715.09, 715.10, 715.18, 715.20, 715.28, $715.30,715.38,715.80,715.89,715.90,715.98)$. Patients who have been diagnosed with the above-listed diseases, hospitalized at least once, or had three outpatient clinic visits were defined as having the diseases.

\subsection{Outcome measurements}


We compared the risks of any UTI ( $\geq 1$ outpatient clinic visit, emergency department visit, or hospitalization for UTI), $\geq 1$ hospitalization for UTI, and $\geq 3$ hospitalizations for UTI between the two cohorts through follow-up until 2015.

\subsection{Ethical statements}

This study was conducted in accordance with the Declaration of Helsinki and was approved by the Institutional Review Board at Chi Mei Medical Center. Although informed consent was waived while using NHIRD data, all datasets are anonymized to protect individuals' confidentiality. Personal identity, birth date, and names are encrypted, and this de-identification process was approved by an independent thirdparty organization[20]. The waiver does not affect the rights and welfare of the participants.

\subsection{Statistical analysis}

We used SAS 9.4 for Windows (SAS Institute, Cary, NC, USA) for all statistical analyses. Pearson chisquare tests were used for categorical variables. We used a competing risk survival analysis to compare the risks of any UTI, $\geq 1$ hospitalization for UTI, and $\geq 3$ hospitalizations for UTI between the two cohorts. Cox proportional hazard regression analyses were used to investigate any UTI's independent predictors in all older patients. A Kaplan-Meier curve and log-rank test were used for comparing any UTI between the two cohorts during the follow-up period. We set the significance level at $p<.05$ (two-tailed).

\section{Results}

A total of 8599 patients with OA and 8599 patients without OA were identified for the present study (Table 1). In both cohorts, individuals aged 65-74 years comprised the largest age subgroup (65.7\%), followed by $75-84$ years $(30.1 \%)$, and $\geq 85$ years $(4.2 \%)$. The male percentage was $42.4 \%$. Compared with patients without OA, patients with OA had a higher prevalence of past histories of UTI, BPH, an indwelling urinary catheter, cerebrovascular disease, and urolithiasis, but a lower prevalence of dementia. There was no significant difference in diabetes between the two cohorts.

Patients with OA had an increased risk of any UTI than those without OA after adjusting for a history of $\mathrm{UTI}, \mathrm{BPH}$, an indwelling urinary catheter, cerebrovascular disease, diabetes, dementia, and urolithiasis (adjusted hazard ratio [AHR]: 1.72; 95\% confidence interval [Cl]: 1.64-1.80) (Table 2). The increased risk was also found in the stratified analyses, including age subgroups, sex, past histories of UTI, BPH, indwelling urinary catheter, cerebrovascular disease, and diabetes. The increased risk of any UTI was most prominent in the age subgroup of $\geq 85$ years (AHR: $2.59 ; 95 \% \mathrm{Cl}: 2.00-3.36$ ). The Kaplan-Meier curve and the log-rank test also revealed an increased risk of any UTI in patients with OA than those without OA (Figure 1). 
In the comparison of $\geq 1$ hospitalization for UTI and $\geq 3$ hospitalizations for UTI, patients with OA had an increased risk than those without OA (AHR: 1.13; 95\% Cl: 1.06-1.19 and AHR: 1.25 ; 95\% Cl: 1.13-1.38, respectively) (Table 3 and Table 4). In the age subgroup of $65-74$, the differences in risk of $\geq 1$ hospitalization for UTI and $\geq 3$ hospitalizations for UTI were not significant between the two cohorts. Compared with other age subgroups, aged $\geq 85$ years had the most prominent risk of $\geq 1$ hospitalization for UTI (AHR: 1.62; 95\% Cl: 1.25-2.10) and $\geq 3$ hospitalizations for UTI (AHR: 2.37; 95\% Cl: 1.47-3.82).

In addition to OA, other independent predictors for any UTI in all older patients were older age (AHR: 1.32; 95\% Cl: $1.27-1.39$ in $75-84$ years and AHR: $1.52 ; 95 \% \mathrm{Cl}$ : $1.36-1.70$ in $\geq 85$ years), female sex (AHR: 1.47; $95 \%$ Cl: $1.41-1.54$ ), a past history of UTI (AHR: 2.95; 95\% Cl: 2.67-3.26), BPH (AHR: $1.43 ; 95 \% \mathrm{Cl}$ : 1.31-1.57), an indwelling urinary catheter (AHR: 1.30; 95\% Cl: 1.23-1.38), cerebrovascular disease (AHR: 1.39; 95\% Cl: 1.29-1.49), diabetes (AHR: 1.34; 95\% Cl: 1.27-1.42), dementia (AHR: 1.44; 95\% Cl: 1.23-1.68), and urolithiasis (AHR: 1.29; 95\% Cl: 1.06-1.57) (Table 5). Compared with patients without OA, patients with subtypes of $O A$, including the upper limbs, lower limbs, spine, other areas, also had an increased risk of any UTI.

\section{Discussion}

The present study showed that OA, including its subtypes, was associated with an increased risk of subsequent UTI in older patients. The impact of OA on subsequent UTI was most prominent in the age subgroup of $\geq 85$ years. In addition to OA, older age, female sex, a history of UTI, an indwelling urinary catheter, cerebrovascular disease, diabetes, dementia, and urolithiasis were also independent predictors for any UTI.

A possible explanation for UTI's increased risk is that patients with OA have decreased physical activity and even immobilization due to pain. This reduced activity predisposes them to inferior body function, sarcopenia and frailty, diabetes, and immune deficiencies related to UTI[10, 15, 21-23]. A study by Rosemann et al. reported that patients with OA of the lower limb had decreased physical activity than those without OA[21]. Another study by Hirata et al. found that more than $40 \%$ of women with hip OA were physically inactive and lacked moderate-intensity activity[24]. A national study by Zhu et al. reported that a greater number of bedridden days was an independent risk factor for UTI[25]. A study by Shang et al. about patients in home health care reported that limited physical function status was a risk factor for infections, including UTI[26]. In contrast to decreased physical activity, a large cohort study by Roger at al. reported that avoiding immobilization and an ability to walk were associated with a $69 \%$ lower hospitalization rate for UTI in older adults admitted to a skilled nursing facility[15]. Even in residents with severe mobility problems, including being in a wheelchair or having a missing limb, maintaining or improving mobility (in bed or when transferring) could reduce the risk of hospitalization for UTI by $38 \%$ to $80 \%[15]$.

A decrease in physical activity may cause the inability to urinate frequently, urinary retention, and urolithiasis, and then increase UTI risk[15, 25]. Decreased physical activity may decrease the abdominal 
organs' pressure on the urinary bladder and decrease the urge to urinate, even when the bladder is full[27]. The bone will turnover to create hypercalciuria, and urine will collect in the lower portions of the renal calyces when the body is immobilized or in the supine position, which increases the risk of renal calculi formation even further[28]. Physical inactivity is also a major contributing factor for sarcopenia, frailty, and adverse outcomes[22, 29]. Sarcopenia and frailty are also associated with impaired bladder function, which may increase UTI risk[30]. Therefore, the impact of OA is broad. Also, many adverse outcomes associated with $\mathrm{OA}$ affect each other and result in a vicious circle.

The increased risk of UTI was more prominent in the age subgroup of $\geq 85$ years and suggested that this older population is more sensitive to the effects of OA on developing subsequent UTI. In addition to OA, the present study found that older age, female sex, a history of UTI, an indwelling urinary catheter, cerebrovascular disease, diabetes, dementia, and urolithiasis were also independent predictors of UTI, which is compatible with previous studies $[14,15]$. All subtypes of $O A$, including the upper limbs, lower limbs, spine, and other areas, were associated with increased UTI risk. There was no study about comparing subtypes of OA and subsequent UTI. The results suggest that the influence of pain and decreased physical activity are specific to older adults, regardless of OA type.

The present study's major strengths are its nationwide design, large sample size, and the clarification of an uncertain issue. The limitations are as follows. First, detailed information related to UTI, including activities of daily living, was not available in the NHIRD, which may confound the present results. However, we had matched age, sex, and adjusted the potential risk factors for UTI. Thus, we believe that the confounding effect is minimal. Second, although we found an association between OA and UTI, the causal relationship between OA and UTI could not be entirely clarified because there is a complex interaction among OA, UTI, and other comorbidities. Third, the present result may not be generalized to other nations because of the differences in race, culture, and medical insurance, and, therefore, further studies in other nations are warranted.

\section{Conclusions}

This nationwide population-based cohort study showed that UTI's risk increased in older patients with OA, especially in the age subgroup of $\geq 85$ years old. Decreased physical activity in older patients with $O A$ may be the major contributing factor. In addition to OA, other independent predictors for UTI were older age, female sex, a history of UTI, an indwelling urinary catheter, cerebrovascular disease, diabetes, dementia, and urolithiasis. We suggest appropriate management, including pain control, rehabilitation, surgery, and controlling other risk factors for UTI in older adults with OA to prevent subsequent UTI. Further studies, including recruiting data of daily activity and validation in other nations, are warranted.

\section{Abbreviations}

UTI: urinary tract infection 
OA: osteoarthritis

LHID: Longitudinal Health Insurance Database

NHIRD: National Health Insurance Research Database

ICD-9-CM: International Classification of Diseases, Ninth Revision, Clinical Modification

BPH: benign prostatic hyperplasia

AHR: adjusted hazard ratio

Cl: confidence interval

\section{Declarations}

\section{Availability of data and materials}

Data are available from the National Health Insurance Research Database (NHIRD) published by Taiwan National Health Insurance Bureau. Due to legal restrictions imposed by the government of Taiwan in relation to the "Personal Information Protection Act," data cannot be made publicly available. Requests for data can be sent as a formal proposal to the NHIRD (http://nhird.nhri.org.tw).

\section{Ethics approval and consent to participate}

This study was approved by the Institutional Review Board at Chi-Mei Medical Center (IRB number: 10910-E01) and conducted according to the Declaration of Helsinki. Because the LHID2000 used in this study consists of unidentifiable and secondary data released to the public for research, informed consent was waived by the institutional review board of the Chi Mei Medical Center. The waiver does not affect the rights and welfare of the participants.

\section{Consent for publication}

Not applicable.

\section{Competing interests}

All authors denied any competing interests.

\section{Funding}

Nil.

\section{Authors' contributions}


WHW, THT, YWC, and CCH ( $8^{\text {th }}$ author) designed and conceived this study and wrote the manuscript. $\mathrm{CHH}$ and YCC performed the statistical analysis and wrote the manuscript. $\mathrm{CCH}$ ( $4^{\text {th }}$ author), HJL, and JJW provided professional suggestions and wrote the manuscript. All authors read and approved the final manuscript.

\section{Acknowledgments}

We thank Enago for the English revision.

\section{References}

1. U.S. Census Bureau. Demographic Turning Points. Population Projections for the United States: $\mathbf{2 0 2 0}$ to 2060. [https://www.prb.org/aging-unitedstates-fact-sheet/]

2. National Development Council. Aging indicators [https://pop-proj.ndc.gov.tw/chart.aspx? $\mathrm{C}=10$ \&uid=66\&pid=60]

3. Curns AT, Holman RC, Sejvar JJ, Owings MF, Schonberger LB: Infectious disease hospitalizations among older adults in the United States from 1990 through 2002. Arch Intern Med 2005, 165(21):2514-2520.

4. Tsan L, Davis C, Langberg R, Hojlo C, Pierce J, Miller M, Gaynes R, Gibert C, Montgomery O, Bradley S et al: Prevalence of nursing home-associated infections in the Department of Veterans Affairs nursing home care units. Am J Infect Control 2008, 36(3):173-179.

5. Cotter M, Donlon S, Roche F, Byrne H, Fitzpatrick F: Healthcare-associated infection in Irish long-term care facilities: results from the First National Prevalence Study. J Hosp Infect 2012, 80(3):212-216.

6. Medina $\mathrm{M}$, Castillo-Pino $\mathrm{E}$ : An introduction to the epidemiology and burden of urinary tract infections. Ther Adv Urol 2019, 11:1756287219832172.

7. Arden N, Nevitt MC: Osteoarthritis: epidemiology. Best Pract Res Clin Rheumatol 2006, 20(1):3-25.

8. Dash SK, Panigrahi R, Palo N, Priyadarshi A, Biswal M: Fragility Hip Fractures in Elderly Patients in Bhubaneswar, India (2012-2014): A Prospective Multicenter Study of 1031 Elderly Patients. Geriatr Orthop Surg Rehabil 2015, 6(1):11-15.

9. Palo N, Chandel SS, Dash SK, Arora G, Kumar M, Biswal MR: Effects of Osteoarthritis on Quality of life in Elderly Population of Bhubaneswar, India: A Prospective Multicenter Screening and Therapeutic Study of 2854 Patients. Geriatr Orthop Surg Rehabil 2015, 6(4):269-275.

10. French HP, Galvin R, Horgan NF, Kenny RA: Prevalence and burden of osteoarthritis amongst older people in Ireland: findings from The Irish LongituDinal Study on Ageing (TILDA). Eur J Public Health 2016, 26(1):192-198.

11. Esclarin De Ruz A, Garcia Leoni E, Herruzo Cabrera R: Epidemiology and risk factors for urinary tract infection in patients with spinal cord injury. $J$ Urol 2000, 164(4):1285-1289.

12. Tsai M-H, Tsay W-I, Her S-H, Ho C-H, Chen Y-C, Hsu C-C, Wang J-J, Huang C-C: Long-term mortality in older adults with chronic pain: a nationwide population-based study in Taiwan. European Geriatric 
Medicine 2019, 10(5):777-784.

13. Chiu YW, Wu CS, Chen PC, Wei YC, Hsu LY, Wang SH: Risk of acute mesenteric ischemia in patients with diabetes: A population-based cohort study in Taiwan. Atherosclerosis 2020, 296:18-24.

14. Rowe TA, Juthani-Mehta M: Urinary tract infection in older adults. Aging health 2013, 9(5).

15. Rogers MA, Fries BE, Kaufman SR, Mody L, McMahon LF, Jr., Saint S: Mobility and other predictors of hospitalization for urinary tract infection: a retrospective cohort study. BMC Geriatr 2008, 8:31.

16. Ke YT, Peng AC, Shu YM, Chung MH, Tsai KT, Chen PJ, Weng TC, Hsu CC, Lin HJ, Huang CC:

Prevalence of Geriatric Syndromes and the Need for Hospice Care in Older Patients of the Emergency Department: A Study in an Asian Medical Center. Emerg Med Int 2020, 2020:7174695.

17. Liu YL, Chu LL, Su HC, Tsai KT, Kao PH, Chen JF, Hsieh HC, Lin HJ, Hsu CC, Huang CC: Impact of Computer-Based and Pharmacist-Assisted Medication Review Initiated in the Emergency Department. J Am Geriatr Soc 2019, 67(11):2298-2304.

18. Ke YT, Peng AC, Shu YM, Chung MH, Tsai KT, Chen PJ, Weng TC, Hsu CC, Lin HJ, Huang CC: Emergency geriatric assessment: A novel comprehensive screen tool for geriatric patients in the emergency department. Am J Emerg Med 2018, 36(1):143-146.

19. Weng TC, Yang YC, Chen PJ, Kuo WF, Wang WL, Ke YT, Hsu CC, Lin KC, Huang CC, Lin HJ: Implementing a novel model for hospice and palliative care in the emergency department: An experience from a tertiary medical center in Taiwan. Medicine (Baltimore) 2017, 96(19):e6943.

20. Lin LY, Warren-Gash C, Smeeth L, Chen PC: Data resource profile: the National Health Insurance Research Database (NHIRD). Epidemiol Health 2018, 40:e2018062.

21. Rosemann T, Kuehlein T, Laux G, Szecsenyi J: Factors associated with physical activity of patients with osteoarthritis of the lower limb. J Eval Clin Pract 2008, 14(2):288-293.

22. Wilson D, Jackson T, Sapey E, Lord JM: Frailty and sarcopenia: The potential role of an aged immune system. Ageing Res Rev 2017, 36:1-10.

23. Knight JA: Physical inactivity: associated diseases and disorders. Ann Clin Lab Sci 2012, 42(3):320337.

24. Hirata S, Ono R, Yamada M, Takikawa S, Nishiyama T, Hasuda K, Kurosaka M: Ambulatory physical activity, disease severity, and employment status in adult women with osteoarthritis of the hip. $J$ Rheumatol 2006, 33(5):939-945.

25. Zhu C, Liu H, Wang Y, Jiao J, Li Z, Cao J, Song B, Jin J, Liu Y, Wen X et al: Prevalence, incidence, and risk factors of urinary tract infection among immobile inpatients in China: a prospective, multi-centre study. J Hosp Infect 2020, 104(4):538-544.

26. Shang J, Wang J, Adams V, Ma C: Risk factors for infection in home health care: Analysis of national Outcome and Assessment Information Set data. Res Nurs Health 2020, 43(4):373-386.

27. Hill WG: Control of urinary drainage and voiding. Clin J Am Soc Nephro/2015, 10(3):480-492.

28. Pietrow PK, Karellas ME: Medical management of common urinary calculi. Am Fam Physician 2006, 74(1):86-94. 
29. Beaudart C, Zaaria M, Pasleau F, Reginster JY, Bruyere O: Health Outcomes of Sarcopenia: A Systematic Review and Meta-Analysis. PLoS One 2017, 12(1):e0169548.

30. Majima T, Funahashi Y, Matsukawa Y, Inoue S, Sassa N, Kato M, Yamamoto T, Gotoh M: Investigation of the relationship between bladder function and sarcopenia using pressure flow studies in elderly male patients. Neurourol Urodyn 2019, 38(5):1417-1422.

\section{Tables}

Table 1

Comparison of demographic characteristics between older patients with and without OA.

\begin{tabular}{|llll|}
\hline Variables & With OA & Without OA & p-value \\
\hline Age subgroup & $\mathbf{n = 8 5 9 9}$ & $\mathbf{n = 8 5 9 9}$ & \\
\hline 65-74 years (\%) & $5649(65.7)$ & $5649(65.7)$ & $>0.999$ \\
\hline $75-84$ years (\%) & $2590(30.1)$ & $2590(30.1)$ & \\
\hline$\geq 85$ years (\%) & $360(4.2)$ & $360(4.2)$ & \\
\hline Sex & & & $>0.999$ \\
\hline Male & $3642(42.4)$ & $3642(42.4)$ & \\
\hline Female & $4957(57.7)$ & $4957(57.7)$ & $<0.001$ \\
\hline History & & & $<0.001$ \\
\hline UTI & $468(5.4)$ & $362(4.2)$ & $<0.001$ \\
\hline BPH & $635(7.4)$ & $360(4.2)$ & 0.016 \\
\hline Indwelling urinary catheter & $1752(20.4)$ & $936(10.9)$ & 0.319 \\
\hline Cerebrovascular disease & $801(9.3)$ & $797(9.3)$ & $<0.001$ \\
\hline Diabetes & $1290(15.0)$ & $1337(15.6)$ & $<0.001$ \\
\hline Dementia & $118(1.4)$ & $189(2.2)$ & \\
\hline Urolithiasis & $103(1.2)$ & $63(0.7)$ & $5589(65.0)$ \\
\hline Mortality & $4168(48.5)$ & $4773(55.5)$ & \\
\hline Any UTI at follow-up & $5947(69.2)$ & & \\
\hline Data are presented as number (percentage) or mean \pm SD. SD, standard deviation; OA, osteoarthritis; & \\
\hline UTI, urinary tract infection; BPH, benign prostatic hyperplasia. & & \\
\hline
\end{tabular}


Table 2

Comparison of the risk of any UTI between older patients with and without OA using competing risk survival analysis.

\begin{tabular}{|c|c|c|c|c|c|c|c|}
\hline \multirow[t]{2}{*}{ Variable } & \multicolumn{2}{|l|}{ With OA } & \multicolumn{2}{|c|}{ Without OA } & \multirow{2}{*}{$\begin{array}{l}\text { Crude HR } \\
(95 \% \mathrm{Cl})\end{array}$} & \multirow{2}{*}{$\begin{array}{l}\text { AHR } \\
(95 \% \mathrm{Cl}) *\end{array}$} & \multirow{2}{*}{$p$ valuet } \\
\hline & $\begin{array}{l}\text { Mortality } \\
\text { (\%) }\end{array}$ & UTI (\%) & $\begin{array}{l}\text { Mortality } \\
\text { (\%) }\end{array}$ & UTI (\%) & & & \\
\hline Overall analysis & $\begin{array}{l}1243 \\
(14.5)\end{array}$ & $\begin{array}{l}5947 \\
(69.2)\end{array}$ & $\begin{array}{l}2333 \\
(27.1)\end{array}$ & $\begin{array}{l}4773 \\
(55.5)\end{array}$ & $\begin{array}{l}1.86 \\
(1.78- \\
1.94)\end{array}$ & $\begin{array}{l}1.72 \\
(1.64- \\
1.80)\end{array}$ & $<001$ \\
\hline \multicolumn{8}{|l|}{$\begin{array}{l}\text { Stratified } \\
\text { analysis }\end{array}$} \\
\hline \multicolumn{8}{|l|}{ Age (years) } \\
\hline $65-74$ years $(\%)$ & $\begin{array}{l}589 \\
(10.4)\end{array}$ & $\begin{array}{l}3866 \\
(68.4)\end{array}$ & $\begin{array}{l}1295 \\
(22.9)\end{array}$ & $\begin{array}{l}3075 \\
(54.4)\end{array}$ & $\begin{array}{l}1.87 \\
(1.78- \\
1.98)\end{array}$ & $\begin{array}{l}1.76 \\
(1.66- \\
1.85)\end{array}$ & $\begin{array}{l}< \\
0.001\end{array}$ \\
\hline $75-84$ years $(\%)$ & $\begin{array}{l}555 \\
(21.4)\end{array}$ & $\begin{array}{l}1826 \\
(70.5)\end{array}$ & $\begin{array}{l}871 \\
(33.6)\end{array}$ & $\begin{array}{l}1521 \\
(58.7)\end{array}$ & $\begin{array}{l}1.72 \\
(1.59- \\
1.87)\end{array}$ & $\begin{array}{l}1.62 \\
(1.49- \\
1.76)\end{array}$ & $\begin{array}{l}< \\
0.001\end{array}$ \\
\hline$\geq 85$ years $(\%)$ & $\begin{array}{l}99 \\
(27.5)\end{array}$ & $\begin{array}{l}255 \\
(70.8)\end{array}$ & $\begin{array}{l}167 \\
(46.4)\end{array}$ & $\begin{array}{l}177 \\
(49.2)\end{array}$ & $\begin{array}{l}2.77 \\
(2.14- \\
3.57)\end{array}$ & $\begin{array}{l}2.59 \\
(2.00- \\
3.36)\end{array}$ & $<0.001$ \\
\hline \multicolumn{8}{|l|}{ Sex } \\
\hline Male & $\begin{array}{l}688 \\
(18.9)\end{array}$ & $\begin{array}{l}2246 \\
(61.7)\end{array}$ & $\begin{array}{l}1214 \\
(33.3)\end{array}$ & $\begin{array}{l}1726 \\
(47.4)\end{array}$ & $\begin{array}{l}1.88 \\
(1.75- \\
2.02)\end{array}$ & $\begin{array}{l}1.75 \\
(1.63- \\
1.88)\end{array}$ & $<0.001$ \\
\hline Female & $\begin{array}{l}555 \\
(11.2)\end{array}$ & $\begin{array}{l}3701 \\
(74.7)\end{array}$ & $\begin{array}{l}1119 \\
(22.6)\end{array}$ & $\begin{array}{l}3047 \\
(61.5)\end{array}$ & $\begin{array}{l}1.84 \\
(1.74- \\
1.94)\end{array}$ & $\begin{array}{l}1.73 \\
(1.63- \\
1.83)\end{array}$ & $\begin{array}{l}< \\
0.001\end{array}$ \\
\hline \multicolumn{8}{|l|}{ History } \\
\hline UTI & $21(4.5)$ & $\begin{array}{l}431 \\
(92.1)\end{array}$ & $0(0.0)$ & $\begin{array}{l}362 \\
(100.0)\end{array}$ & - & - & - \\
\hline $\mathrm{BPH}$ & $\begin{array}{l}84 \\
(13.2)\end{array}$ & $\begin{array}{l}482 \\
(75.9)\end{array}$ & $\begin{array}{l}77 \\
(21.4)\end{array}$ & $\begin{array}{l}266 \\
(73.9)\end{array}$ & $\begin{array}{l}1.76 \\
(1.39- \\
2.22)\end{array}$ & $\begin{array}{l}1.47 \\
(1.16- \\
1.87)\end{array}$ & 0.002 \\
\hline $\begin{array}{l}\text { Indwelling } \\
\text { urinary catheter }\end{array}$ & $\begin{array}{l}321 \\
(18.3)\end{array}$ & $\begin{array}{l}1269 \\
(72.4)\end{array}$ & $\begin{array}{l}288 \\
(30.8)\end{array}$ & $\begin{array}{l}602 \\
(64.3)\end{array}$ & $\begin{array}{l}2.05 \\
(1.79- \\
2.35)\end{array}$ & $\begin{array}{l}1.92 \\
(1.67- \\
2.21)\end{array}$ & $\begin{array}{l}< \\
0.001\end{array}$ \\
\hline
\end{tabular}

*Adjusted for UTI, BPH, indwelling urinary catheter, cerebrovascular disease, diabetes, dementia, and urolithiasis. †AHR. UTI, urinary tract infection; OA, osteoarthritis; HR, hazard ratio; AHR, adjusted hazard ratio; $\mathrm{Cl}$, confidence interval; $\mathrm{BPH}$, benign prostatic hyperplasia. 


\begin{tabular}{|c|c|c|c|c|c|c|c|}
\hline \multirow[t]{2}{*}{ Variable } & \multicolumn{2}{|l|}{ With OA } & \multicolumn{2}{|c|}{ Without OA } & \multirow{2}{*}{$\begin{array}{l}\text { Crude HR } \\
(95 \% \mathrm{Cl})\end{array}$} & \multirow{2}{*}{$\begin{array}{l}\text { AHR } \\
(95 \% \mathrm{Cl})^{*}\end{array}$} & \multirow{2}{*}{$\begin{array}{l}p- \\
\text { valuet }\end{array}$} \\
\hline & $\begin{array}{l}\text { Mortality } \\
(\%)\end{array}$ & UTI (\%) & $\begin{array}{l}\text { Mortality } \\
\text { (\%) }\end{array}$ & UTI (\%) & & & \\
\hline $\begin{array}{l}\text { Cerebrovascular } \\
\text { disease }\end{array}$ & $\begin{array}{l}133 \\
(16.6)\end{array}$ & $\begin{array}{l}613 \\
(76.5)\end{array}$ & $\begin{array}{l}209 \\
(26.2)\end{array}$ & $\begin{array}{l}553 \\
(69.4)\end{array}$ & $\begin{array}{l}1.62 \\
(1.40- \\
1.87)\end{array}$ & $\begin{array}{l}1.49 \\
(1.28- \\
1.73)\end{array}$ & $<.001$ \\
\hline Diabetes & $\begin{array}{l}195 \\
(15.1)\end{array}$ & $\begin{array}{l}956 \\
(74.1)\end{array}$ & $\begin{array}{l}340 \\
(25.4)\end{array}$ & $\begin{array}{l}918 \\
(68.7)\end{array}$ & $\begin{array}{l}1.61 \\
(1.44- \\
1.79)\end{array}$ & $\begin{array}{l}1.48 \\
(1.32- \\
1.66)\end{array}$ & $\begin{array}{l}< \\
0.001\end{array}$ \\
\hline Dementia & $\begin{array}{l}28 \\
(23.7)\end{array}$ & $\begin{array}{l}84 \\
(71.2)\end{array}$ & $\begin{array}{l}47 \\
(24.9)\end{array}$ & $\begin{array}{l}139 \\
(73.5)\end{array}$ & $\begin{array}{l}1.22 \\
(0.90- \\
1.66)\end{array}$ & $\begin{array}{l}1.11 \\
(0.80- \\
1.54)\end{array}$ & 0.541 \\
\hline Urolithiasis & $5(4.9)$ & $\begin{array}{l}87 \\
(84.5)\end{array}$ & $4(6.4)$ & $\begin{array}{l}53 \\
(84.1)\end{array}$ & $\begin{array}{l}1.81 \\
(1.09- \\
3.00)\end{array}$ & $\begin{array}{l}1.45 \\
(0.86- \\
2.47)\end{array}$ & 0.168 \\
\hline
\end{tabular}


Table 3

Comparison of the risk of $\geq 1$ hospitalization for UTI between older patients with and without OA using competing risk survival analysis.

\begin{tabular}{|c|c|c|c|c|c|c|c|}
\hline \multirow[t]{2}{*}{ Variable } & \multicolumn{2}{|l|}{ With OA } & \multicolumn{2}{|c|}{ Without OA } & \multirow{2}{*}{$\begin{array}{l}\text { Crude HR } \\
(95 \% \mathrm{Cl})\end{array}$} & \multirow{2}{*}{$\begin{array}{l}\text { AHR } \\
(95 \% \mathrm{Cl}) *\end{array}$} & \multirow{2}{*}{$\begin{array}{l}p- \\
\text { valuet }\end{array}$} \\
\hline & $\begin{array}{l}\text { Mortality } \\
\text { (\%) }\end{array}$ & UTI (\%) & $\begin{array}{l}\text { Mortality } \\
\text { (\%) }\end{array}$ & $\begin{array}{l}\text { UTI } \\
\text { (\%) }\end{array}$ & & & \\
\hline Overall analysis & $\begin{array}{l}2241 \\
(26.1)\end{array}$ & $\begin{array}{l}2927 \\
(34.0)\end{array}$ & $\begin{array}{l}3440 \\
(40.0)\end{array}$ & $\begin{array}{l}2623 \\
(30.5)\end{array}$ & $\begin{array}{l}1.19 \\
(1.13- \\
1.26)\end{array}$ & $\begin{array}{l}1.13 \\
(1.06- \\
1.19)\end{array}$ & $<0.001$ \\
\hline \multicolumn{8}{|l|}{$\begin{array}{l}\text { Stratified } \\
\text { analysis }\end{array}$} \\
\hline \multicolumn{8}{|l|}{ Age (years) } \\
\hline $65-74$ years $(\%)$ & $\begin{array}{l}1134 \\
(20.1)\end{array}$ & $\begin{array}{l}1571 \\
(27.8)\end{array}$ & $\begin{array}{l}1915 \\
(33.9)\end{array}$ & $\begin{array}{l}1505 \\
(26.6)\end{array}$ & $\begin{array}{l}1.10 \\
(1.03- \\
1.19)\end{array}$ & $\begin{array}{l}1.04 \\
(0.97- \\
1.13)\end{array}$ & 0.253 \\
\hline $75-84$ years $(\%)$ & $\begin{array}{l}944 \\
(36.5)\end{array}$ & $\begin{array}{l}1183 \\
(45.7)\end{array}$ & $\begin{array}{l}1302 \\
(50.3)\end{array}$ & $\begin{array}{l}998 \\
(38.5)\end{array}$ & $\begin{array}{l}1.24 \\
(1.13- \\
1.35)\end{array}$ & $\begin{array}{l}1.21 \\
(1.10- \\
1.32)\end{array}$ & $<0.001$ \\
\hline$\geq 85$ years $(\%)$ & $\begin{array}{l}163 \\
(45.3)\end{array}$ & $\begin{array}{l}173 \\
(48.1)\end{array}$ & $\begin{array}{l}223 \\
(61.9)\end{array}$ & $\begin{array}{l}120 \\
(33.3)\end{array}$ & $\begin{array}{l}1.67 \\
(1.29- \\
2.15)\end{array}$ & $\begin{array}{l}1.62 \\
(1.25- \\
2.10)\end{array}$ & $<0.001$ \\
\hline \multicolumn{8}{|l|}{ Sex } \\
\hline Male & $\begin{array}{l}1194 \\
(32.8)\end{array}$ & $\begin{array}{l}1013 \\
(27.8)\end{array}$ & $\begin{array}{l}1738 \\
(47.7)\end{array}$ & $\begin{array}{l}843 \\
(23.2)\end{array}$ & $\begin{array}{l}1.27 \\
(1.16- \\
1.40)\end{array}$ & $\begin{array}{l}1.19 \\
(1.08- \\
1.31)\end{array}$ & $<0.001$ \\
\hline Female & $\begin{array}{l}1047 \\
(21.1)\end{array}$ & $\begin{array}{l}1914 \\
(38.6)\end{array}$ & $\begin{array}{l}1702 \\
(34.3)\end{array}$ & $\begin{array}{l}1780 \\
(35.9)\end{array}$ & $\begin{array}{l}1.14 \\
(1.07- \\
1.22)\end{array}$ & $\begin{array}{l}1.11 \\
(1.03- \\
1.19)\end{array}$ & 0.004 \\
\hline \multicolumn{8}{|l|}{ History } \\
\hline UTI & $\begin{array}{l}113 \\
(24.2)\end{array}$ & $\begin{array}{l}212 \\
(45.3)\end{array}$ & $\begin{array}{l}127 \\
(35.1)\end{array}$ & $\begin{array}{l}197 \\
(54.4)\end{array}$ & $\begin{array}{l}0.86 \\
(0.69- \\
1.07)\end{array}$ & $\begin{array}{l}0.87 \\
(0.69- \\
1.09)\end{array}$ & 0.215 \\
\hline $\mathrm{BPH}$ & $\begin{array}{l}209 \\
(32.9)\end{array}$ & $\begin{array}{l}212 \\
(33.4)\end{array}$ & $\begin{array}{l}175 \\
(48.6)\end{array}$ & $\begin{array}{l}136 \\
(37.8)\end{array}$ & $\begin{array}{l}0.89 \\
(0.71- \\
1.12)\end{array}$ & $\begin{array}{l}0.80 \\
(0.63- \\
1.02)\end{array}$ & 0.075 \\
\hline $\begin{array}{l}\text { Indwelling urinary } \\
\text { catheter }\end{array}$ & $\begin{array}{l}562 \\
(32.1)\end{array}$ & $\begin{array}{l}778 \\
(44.4)\end{array}$ & $\begin{array}{l}419 \\
(44.8)\end{array}$ & $\begin{array}{l}425 \\
(45.4)\end{array}$ & $\begin{array}{l}1.39 \\
(1.20- \\
1.62)\end{array}$ & $\begin{array}{l}1.41 \\
(1.21- \\
1.65)\end{array}$ & $\begin{array}{l}< \\
0.001\end{array}$ \\
\hline
\end{tabular}

*Adjusted for UTI, BPH, indwelling urinary catheter, cerebrovascular disease, diabetes, dementia, and urolithiasis. †AHR. UTI, urinary tract infection; OA, osteoarthritis; HR, hazard ratio; AHR, adjusted hazard ratio; $\mathrm{Cl}$, confidence interval; $\mathrm{BPH}$, benign prostatic hyperplasia. 


\begin{tabular}{|c|c|c|c|c|c|c|c|}
\hline \multirow[t]{2}{*}{ Variable } & \multicolumn{2}{|l|}{ With OA } & \multicolumn{2}{|c|}{ Without OA } & \multirow{2}{*}{$\begin{array}{l}\text { Crude HR } \\
(95 \% \mathrm{Cl})\end{array}$} & \multirow{2}{*}{$\begin{array}{l}\text { AHR } \\
(95 \% \mathrm{Cl})^{*}\end{array}$} & \multirow{2}{*}{$p-$} \\
\hline & $\begin{array}{l}\text { Mortality } \\
\text { (\%) }\end{array}$ & UTI (\%) & $\begin{array}{l}\text { Mortality } \\
\text { (\%) }\end{array}$ & $\begin{array}{l}\text { UTI } \\
\text { (\%) }\end{array}$ & & & \\
\hline $\begin{array}{l}\text { Cerebrovascular } \\
\text { disease }\end{array}$ & $\begin{array}{l}250 \\
(31.2)\end{array}$ & $\begin{array}{l}382 \\
(47.7)\end{array}$ & $\begin{array}{l}313 \\
(39.3)\end{array}$ & $\begin{array}{l}419 \\
(52.6)\end{array}$ & $\begin{array}{l}0.93 \\
(0.80- \\
1.07)\end{array}$ & $\begin{array}{l}0.90 \\
(0.77- \\
1.05)\end{array}$ & 0.189 \\
\hline Diabetes & $\begin{array}{l}380 \\
(29.5)\end{array}$ & $\begin{array}{l}596 \\
(46.2)\end{array}$ & $\begin{array}{l}548 \\
(41.0)\end{array}$ & $\begin{array}{l}632 \\
(47.3)\end{array}$ & $\begin{array}{l}1.02 \\
(0.90- \\
1.14)\end{array}$ & $\begin{array}{l}0.99 \\
(0.88- \\
1.12)\end{array}$ & 0.852 \\
\hline Dementia & $\begin{array}{l}46 \\
(39.0)\end{array}$ & $\begin{array}{l}61 \\
(51.7)\end{array}$ & $\begin{array}{l}65 \\
(34.4)\end{array}$ & $\begin{array}{l}118 \\
(62.4)\end{array}$ & $\begin{array}{l}0.74 \\
(0.55- \\
1.00)\end{array}$ & $\begin{array}{l}0.70 \\
(0.51- \\
0.96)\end{array}$ & 0.026 \\
\hline Urolithiasis & $\begin{array}{l}18 \\
(17.5)\end{array}$ & $\begin{array}{l}41 \\
(39.8)\end{array}$ & $\begin{array}{l}21 \\
(33.3)\end{array}$ & $\begin{array}{l}33 \\
(52.4)\end{array}$ & $\begin{array}{l}0.77 \\
(0.47- \\
1.28)\end{array}$ & $\begin{array}{l}0.65 \\
(0.37- \\
1.17)\end{array}$ & 0.151 \\
\hline
\end{tabular}


Table 4

Comparison of the risk of $\geq 3$ hospitalizations for UTI between older patients with and without OA using competing risk survival analysis.

\begin{tabular}{|c|c|c|c|c|c|c|c|}
\hline \multirow[t]{3}{*}{ Variable } & \multicolumn{2}{|l|}{ With OA } & \multicolumn{2}{|c|}{ Without OA } & \multirow{3}{*}{$\begin{array}{l}\text { Crude HR } \\
(95 \% \mathrm{Cl})\end{array}$} & \multirow{3}{*}{$\begin{array}{l}\text { AHR } \\
(95 \% \mathrm{Cl})^{*}\end{array}$} & \multirow{3}{*}{$\begin{array}{l}p- \\
\text { valuet }\end{array}$} \\
\hline & Mortality & UTI & Mortality & UTI & & & \\
\hline & $(\%)$ & (\%) & (\%) & (\%) & & & \\
\hline Overall analysis & $\begin{array}{l}3427 \\
(39.9)\end{array}$ & $\begin{array}{l}963 \\
(11.2)\end{array}$ & $\begin{array}{l}4835 \\
(56.2)\end{array}$ & $\begin{array}{l}854 \\
(9.9)\end{array}$ & $\begin{array}{l}1.29 \\
(1.17- \\
1.42)\end{array}$ & $\begin{array}{l}1.25 \\
(1.13- \\
1.38)\end{array}$ & $\begin{array}{l}<.001 \\
0.00\end{array}$ \\
\hline \multicolumn{8}{|l|}{ Stratified analysis } \\
\hline \multicolumn{8}{|l|}{ Age (years) } \\
\hline $65-74$ years $(\%)$ & $\begin{array}{l}1669 \\
(29.6)\end{array}$ & $\begin{array}{l}467 \\
(8.3)\end{array}$ & $\begin{array}{l}2621 \\
(46.4)\end{array}$ & $\begin{array}{l}471 \\
(8.3)\end{array}$ & $\begin{array}{l}1.11 \\
(0.97- \\
1.27)\end{array}$ & $\begin{array}{l}1.07 \\
(0.93- \\
1.22)\end{array}$ & 0.350 \\
\hline 75-84 years (\%) & $\begin{array}{l}1494 \\
(57.7)\end{array}$ & $\begin{array}{l}434 \\
(16.8)\end{array}$ & $\begin{array}{l}1905 \\
(73.6)\end{array}$ & $\begin{array}{l}349 \\
(13.5)\end{array}$ & $\begin{array}{l}1.43 \\
(1.23- \\
1.66)\end{array}$ & $\begin{array}{l}1.42 \\
(1.22- \\
1.65)\end{array}$ & $<0.001$ \\
\hline$\geq 85$ years $(\%)$ & $\begin{array}{l}264 \\
(73.3)\end{array}$ & $\begin{array}{l}62 \\
(17.2)\end{array}$ & $\begin{array}{l}309 \\
(85.8)\end{array}$ & $\begin{array}{l}34 \\
(9.4)\end{array}$ & $\begin{array}{l}2.46 \\
(1.53- \\
3.96)\end{array}$ & $\begin{array}{l}2.37 \\
(1.47- \\
3.82)\end{array}$ & $<0.001$ \\
\hline \multicolumn{8}{|l|}{ Sex } \\
\hline Male & $\begin{array}{l}1664 \\
(45.7)\end{array}$ & $\begin{array}{l}325 \\
(8.9)\end{array}$ & $\begin{array}{l}2211 \\
(60.7)\end{array}$ & $\begin{array}{l}252 \\
(6.9)\end{array}$ & $\begin{array}{l}1.42 \\
(1.20- \\
1.68)\end{array}$ & $\begin{array}{l}1.34 \\
(1.13- \\
1.59)\end{array}$ & $<0.001$ \\
\hline Female & $\begin{array}{l}1763 \\
(35.6)\end{array}$ & $\begin{array}{l}638 \\
(12.9)\end{array}$ & $\begin{array}{l}2624 \\
(52.9)\end{array}$ & $\begin{array}{l}602 \\
(12.1)\end{array}$ & $\begin{array}{l}1.23 \\
(1.09- \\
1.38)\end{array}$ & $\begin{array}{l}1.22 \\
(1.08- \\
1.37)\end{array}$ & 0.001 \\
\hline \multicolumn{8}{|l|}{ History } \\
\hline UTI & $\begin{array}{l}191 \\
(40.8)\end{array}$ & $\begin{array}{l}85 \\
(18.2)\end{array}$ & $\begin{array}{l}217 \\
(59.9)\end{array}$ & $\begin{array}{l}88 \\
(24.3)\end{array}$ & $\begin{array}{l}0.96 \\
(0.69- \\
1.34)\end{array}$ & $\begin{array}{l}0.99 \\
(1.71- \\
1.38)\end{array}$ & 0.939 \\
\hline $\mathrm{BPH}$ & $\begin{array}{l}307 \\
(48.4)\end{array}$ & $\begin{array}{l}70 \\
(11.0)\end{array}$ & $\begin{array}{l}252 \\
(70.0)\end{array}$ & $\begin{array}{l}42 \\
(11.7)\end{array}$ & $\begin{array}{l}1.13 \\
(0.75- \\
1.71)\end{array}$ & $\begin{array}{l}1.06 \\
(0.69- \\
1.63)\end{array}$ & 0.798 \\
\hline $\begin{array}{l}\text { Indwelling urinary } \\
\text { catheter }\end{array}$ & $\begin{array}{l}899 \\
(51.3)\end{array}$ & $\begin{array}{l}298 \\
(17.0)\end{array}$ & $\begin{array}{l}653 \\
(69.8)\end{array}$ & $\begin{array}{l}169 \\
(18.1)\end{array}$ & $\begin{array}{l}1.77 \\
(1.38- \\
2.27)\end{array}$ & $\begin{array}{l}1.88 \\
(1.46- \\
2.42)\end{array}$ & $\begin{array}{l}< \\
0.001\end{array}$ \\
\hline
\end{tabular}

*Adjusted for UTI, BPH, indwelling urinary catheter, cerebrovascular disease, diabetes, dementia, and urolithiasis. †AHR. UTI, urinary tract infection; OA, osteoarthritis; HR, hazard ratio; AHR, adjusted hazard ratio; $\mathrm{Cl}$, confidence interval; $\mathrm{BPH}$, benign prostatic hyperplasia. 


\begin{tabular}{|c|c|c|c|c|c|c|c|}
\hline \multirow[t]{3}{*}{ Variable } & \multicolumn{2}{|l|}{ With OA } & \multicolumn{2}{|c|}{ Without OA } & \multirow{3}{*}{$\begin{array}{l}\text { Crude HR } \\
(95 \% \mathrm{Cl})\end{array}$} & \multirow{3}{*}{$\begin{array}{l}\text { AHR } \\
(95 \% \mathrm{Cl}) *\end{array}$} & \multirow{3}{*}{$p-$} \\
\hline & Mortality & UTI & Mortality & UTI & & & \\
\hline & $(\%)$ & (\%) & $(\%)$ & $(\%)$ & & & \\
\hline $\begin{array}{l}\text { Cerebrovascular } \\
\text { disease }\end{array}$ & $\begin{array}{l}399 \\
(49.8)\end{array}$ & $\begin{array}{l}165 \\
(20.6)\end{array}$ & $\begin{array}{l}512 \\
(64.2)\end{array}$ & $\begin{array}{l}196 \\
(24.6)\end{array}$ & $\begin{array}{l}1.03 \\
(0.82- \\
1.28)\end{array}$ & $\begin{array}{l}1.02 \\
(0.81- \\
1.28)\end{array}$ & 0.861 \\
\hline Diabetes & $\begin{array}{l}613 \\
(47.5)\end{array}$ & $\begin{array}{l}225 \\
(17.4)\end{array}$ & $\begin{array}{l}903 \\
(67.5)\end{array}$ & $\begin{array}{l}227 \\
(17.0)\end{array}$ & $\begin{array}{l}1.28 \\
(1.05- \\
1.56)\end{array}$ & $\begin{array}{l}1.27 \\
(1.04- \\
1.55)\end{array}$ & 0.019 \\
\hline Dementia & $\begin{array}{l}75 \\
(63.6)\end{array}$ & $\begin{array}{l}23 \\
(19.5)\end{array}$ & $\begin{array}{l}118 \\
(62.4)\end{array}$ & $\begin{array}{l}62 \\
(32.8)\end{array}$ & $\begin{array}{l}0.63 \\
(0.39- \\
1.03)\end{array}$ & $\begin{array}{l}0.63 \\
(0.38- \\
1.02)\end{array}$ & 0.062 \\
\hline Urolithiasis & $\begin{array}{l}34 \\
(33.0)\end{array}$ & $\begin{array}{l}15 \\
(14.6)\end{array}$ & $\begin{array}{l}33 \\
(52.4)\end{array}$ & $\begin{array}{l}16 \\
(25.4)\end{array}$ & $\begin{array}{l}0.81 \\
(0.37- \\
1.79)\end{array}$ & $\begin{array}{l}0.62 \\
(0.27- \\
1.44)\end{array}$ & 0.266 \\
\hline \multicolumn{8}{|c|}{$\begin{array}{l}\text { *Adjusted for UTI, BPH, indwelling urinary catheter, cerebrovascular disease, diabetes, dementia, and } \\
\text { urolithiasis. } † \text { AHR. UTI, urinary tract infection; OA, osteoarthritis; HR, hazard ratio; AHR, adjusted } \\
\text { hazard ratio; Cl, confidence interval; BPH, benign prostatic hyperplasia. }\end{array}$} \\
\hline
\end{tabular}


Table 5

Independent predictors of any UTI in all older patients by the Cox proportional hazard regression analysis.

Variable
Crude HR

$(95 \% \mathrm{Cl})$
Full model*

$\operatorname{AHR}(95 \% \mathrm{Cl})$

Cohort

Without OA

1 (reference)

1 (reference)

With $O A$

$1.55(1.49-1.62)$

$1.36(1.30-1.43)$

With OA of upper limbs

1.75 (1.29-2.38)

$1.41(1.02-1.96)$

With OA of lower limbs

$1.54(1.41-1.67)$

$1.34(1.23-1.46)$

With OA of spine

$1.64(1.52-1.77)$

$1.42(1.32-1.54)$

With OA of others

$1.58(1.46-1.70)$

$1.42(1.31-1.53)$

Age (years)

65-74

1 (reference)

1 (reference)

75-84

$1.46(1.39-1.53)$

1.32 (1.27-1.39)

$\geq 85$

$1.85(1.66-2.06)$

$1.52(1.36-1.70)$

Sex

Female

Male

History

UTI

$\mathrm{BPH}$

Indwelling urinary catheter

Cerebrovascular disease

Diabetes

Dementia

Urolithiasis
$1.41(1.35-1.67)$

1 (reference)

4.07 (3.69-4.49)

$1.52(1.40-1.66)$

$2.89(2.15-3.88)$

$1.67(1.56-1.79)$

1.45 (1.37-1.54)

1.96(1.67-2.28)

$1.71(1.41-2.07)$
$1.47(1.41-1.54)$

1 (reference)

$1.43(1.31-1.57)$

$1.30(1.23-1.38)$

1.39 (1.29-1.49)

1.34 (1.27-1.42)

$1.44(1.23-1.68)$

1.29 (1.06-1.57)

*Adjusted for age, sex, UTI, BPH, indwelling urinary catheter, cerebrovascular disease, diabetes, dementia, and urolithiasis. ${ }^{\dagger} U T I$, urinary tract infection; OA, osteoarthritis; HR, hazard ratio; AHR, adjusted hazard ratio; $\mathrm{Cl}$, confidence interval; $\mathrm{BPH}$, benign prostatic hyperplasia.

\section{Figures}




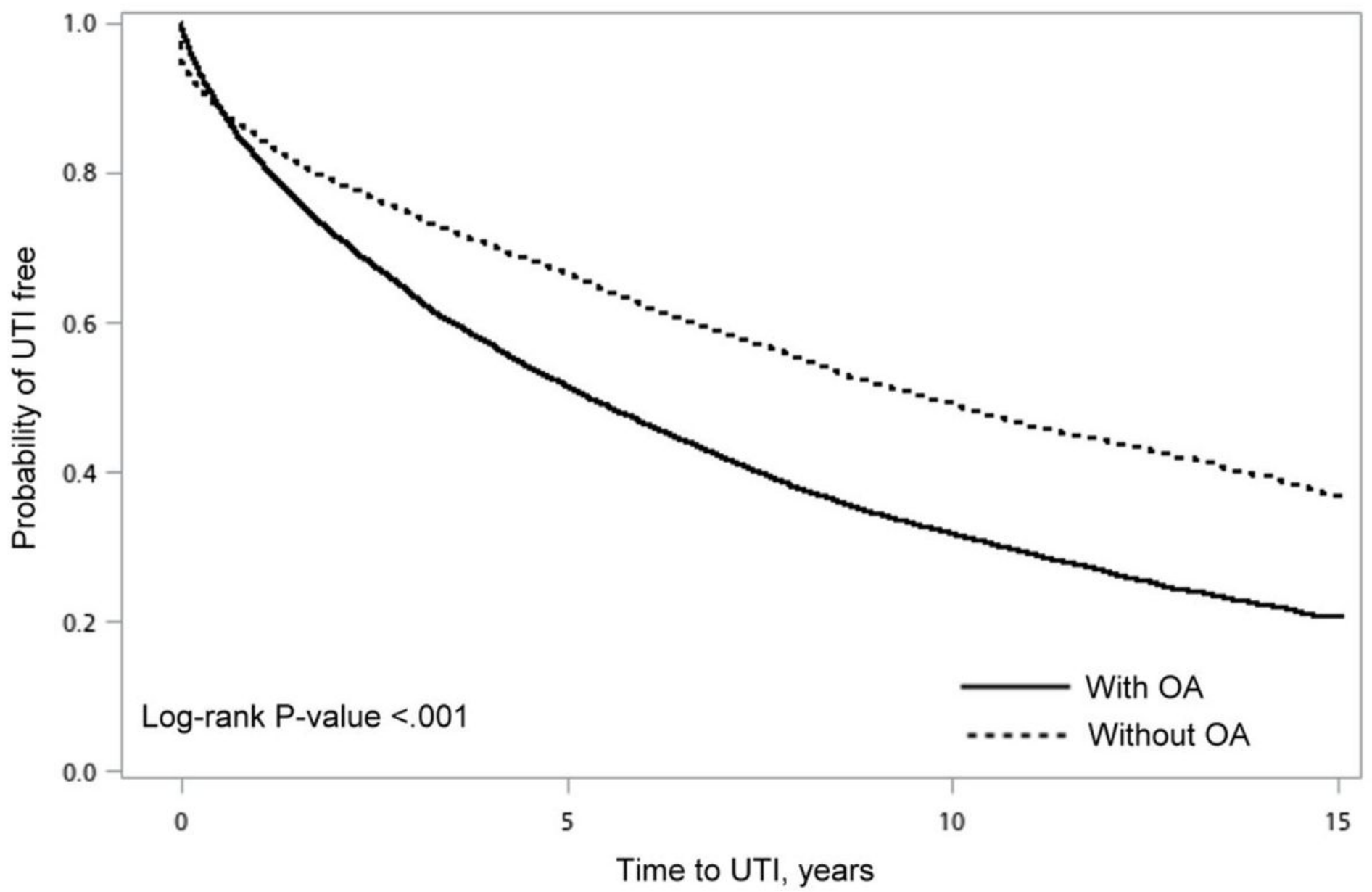

\section{Figure 1}

The Kaplan-Meier curve and log-rank test for comparing the risk of any UTI between older patients with and without OA. UTI, urinary tract infection; OA, osteoarthritis. 